\title{
IMPLEMENTASI TEAMS GAMES TOURNAMENT BERBANTUAN LECTORA UNTUK MENINGKATKAN MOTIVASI DAN HASIL BELAJAR IPS SD
}

\author{
Laila Fatmawati \\ Dosen PGSD FKIP Universitas Ahmad Dahlan Yogyakarta \\ email: laila_fatmawati@ymail.com
}

\begin{abstract}
The purpose of this classroom aaction research was to describe application of cooperative learning teams games tournament type assisted Lectora to improve motivation and learning outcomes in social studies elementary school. Subject were fourth grade student in SD N Tukangan Yogyakarta. Result found application of the cooperative learning type teams games tournament type assisted Lectora improves motivation and learning outcomes in social studies elementary school.
\end{abstract}

Keynote: Teams Games Tornament, Lectora, Motivation, Learning outcomes.

\begin{abstract}
Abstrak: Penelitian tindakan kelas ini bertujuan untuk mendeskripsikan penerapan pembelajaran kooperatif tipe teams games tournament berbantuan Lectora untuk meningkatkan motivasi dan hasil belajar IPS SD. Subjek penelitian adalah siswa kelas IV B SD Negeri Tukangan Yogyakarta. Hasil penelitian menunjukkan penerapan pembelajaran kooperatif tipe teams games tournament berbantuan Lectora dapat meningkatkan motivasi dan hasil belajar IPS SD.
\end{abstract}

Kata Kunci : Teams Games Tornament, Lectora, Motivasi, Hasil Belajar

\section{Pendahuluan}

Guru dan siswa adalah bagian essential dari kegiatan pembelajaran, satu sama lain saling terkait dalam proses interaksi edukatif dengan tugas dan peranan yang berbeda. Dalam proses pembelajaran guru mempunyai tugas untuk mendorong, membimbing, dan memberikan fasilitas belajar bagi siswa untuk mencapai tujuan pendidikan. Guru mempunyai tanggung jawab terhadap seluruh proses belajar siswa di kelas serta membantu perkembangan siswa.

Berhasil tidaknya pencapaian tujuan pendidikan tergantung pada proses pembelajaran yang dijalankan oleh guru dan siswa. Guru sebagai pengelola proses pembelajaran hendaknya berusaha menciptakan kondisi pembelajaran yang

kondusif antara lain dengan penggunaan metode pembelajaran yang disesuaikan dengan kebutuhan siswa. Dengan metode pembelajaran, diharapkan tumbuh berbagai kegiatan belajar siswa agar tercipta interaksi edukatif. Proses interaksi akan berjalan baik kalau siswa lebih banyak aktif dibanding guru. Metode pembelajaran yang baik adalah metode yang menumbuhkan kegiatan belajar siswa, serta menggunakan metode secara bervariasi.

Menurut Syaiful Bahri Djamarah (2006:72-76) metode pembelajaran memiliki kedudukan sebagai strategi pembelajaran dan menumbuhkan motivasi belajar, alat untuk mencapai tujuan pembelajaran”. Guru yang menguasai berbagai metode pembelajaran akan dapat mengarahkan keberhasilan belajar, memudahkan siswa dalam belajar sesuai minat, serta memotivasi usaha kerjasama dalam kegiatan belajar mengajar antara siswa dan guru. Kurangnya penguasaan metode 
mengajar akan menimbulkan masalah antara lain tidak ada kesungguhan belajar pada siswa yang akan berdampak pada menurunnya motivasi siswa untuk belajar sehingga hasil belajar pun menjadi kurang optimal. Oleh karena itu guru harus mampu menyajikan metode pembelajaran yang membangkitkan motivasi belajar siswa sehingga siswa bergairah untuk belajar dan nantinya diharapkan hasil belajar pun akan optimal.

Motivasi belajar merupakan salah satu faktor pendukung keberhasilan pendidikan yang eksistensinya melekat pada diri peserta didik. Ini berarti motivasi belajar merupakan salah satu sub komponen pendidikan yang perlu dikembangkan dalam upaya peningkatan kualitas pendidikan. Motivasi sering dikatakan sebagai dorongan yang mengarahkan seseorang pada kegiatan tertentu. Namun motivasi dapat berubah dan dipengaruhi oleh berbagai aspek. Hal ini sekaligus menunjukkan bahwa motivasi belajar siswa yang masih rendah, dapat ditingkatkan dengan berbagai upaya tertentu, seperti penerapan metode pembelajaran yang tepat bagi siswa.

Proses pembelajaran dapat dikatakan berhasil jika semua aspek pembelajaran dapat saling mendukung dalam menciptakan situasi yang kondusif untuk kegiatan pembelajaran. Proses pembelajaran yang baik tentunya akan berpengaruh pada pemahaman siswa terhadap materi yang disampaikan guru.

Sasaran utama dari kegiatan pembelajaran terletak pada proses belajar peserta didik, yang harus mengutamakan belajar siswa secara aktif, karena sasaran pendidikan adalah proses pembelajaran siswa, bukan semata-mata mengukur hasil belajar siswa.

Seharusnya dalam proses pembelajaran yang aktif adalah siswa, guru hanya berperan sebagai fasilitator, yang tugasnya memberikan bimbingan pada siswa agar mereka mampu mengkonstruksikan sendiri materi pelajaran. Serta menciptakan suasana dan lingkungan belajar yang kondusif sehingga mampu menunjang belajar siswa sesuai dengan minat, bakat, dan kebutuhannya.

Namun selama ini masih banyak guru mengalami kesulitan dalam menciptakan suasana belajar yang kondusif bagi siswa, sehingga sulit bagi guru memotivasi siswa untuk mau belajar lebih giat dan aktif dalam proses pembelajaran, akibatnya hasil belajar siswa tidak optimal. Hal ini antara lain disebabkan penerapan metode pembelajaran yang kurang tepat oleh guru dan kurangnya pemanfaatan media pembelajaran berbasis IT yang menarik bagi siswa.

Penggunaaan metode klasikal atau ceramah dianggap oleh guru sebagai metode paling mudah untuk mengelola kelas dan bisa mengejar target materi yang harus diselesaikan. Dengan metode ceramah peranan guru sangat dominan, guru sebagai subyek penyampai informasi, guru merupakan pusat perhatian, guru lebih banyak berbicara sedangkan murid hanya mendengarkan atau mencatat hal-hal yang penting. Komunikasi yang terjadi cenderung satu arah di mana alat komunikasi yang utama digunakan adalah berbicara. Karena komunikasi yang terjadi hanya satu arah, maka proses belajar mengajar menjadi kurang menarik bahkan membosankan. Meskipun demikian masih banyak yang tetap menggunakan metode ceramah tanpa variasi lain.

Kebiasaan guru menerapkan pembelajaran secara klasikal dan cenderung teacher centered yang bersifat satu arah dapat menyebabkan siswa kurang terlibat secara aktif dalam kegiatan pembelajaran. Akibatnya proses pembelajaran kurang mendorong terjadinya pengembangan siswa yang dinamis, dan timbul budaya berpikir praktis.

Seperti yang dikemukakan oleh Anita Lie (2007) sudah seharusnya guru 
merubah metode ceramah yang diterapkan secara murni tersebut dengan menyusun dan melaksanakan kegiatan pembelajaran yaitu menerapkan prinsip pengetahuan ditemukan, dibentuk, dan dikembangkan oleh siswa, siswa membangun pengetahuan secara aktif, pengajar perlu mengembangkan kompetensi dan kemampuan siswa, pendidik adalah interaksi pribadi diantara para siswa dan interaksi antara guru dengan siswa.

Dari hasil pra observasi, hasil belajar siswa kelas IV B belum optimal, sekitar $35 \%$ siswanya masih memiliki nilai di bawah KKM (65). Dalam tabel lampiran 1 disajikan data nilai mid semester 1 kelas IV B tahun ajaran

2012/2013. Dalam setiap sekolah mempunyai batas tuntas yang digunakan sebagai batas minimal seorang siswa dinyatakan sudah lulus/berhasil menempuh mata pelajaran tertentu. Batas tuntas di SD Negeri 1 Tukangan untuk mata pelajaran IPS adalah 65. Dari 26 siswa kelas IV B, diketahui bahwa siswa yang belum tuntas dan harus mengikuti remidi sebanyak 9 siswa. Hal tersebut dapat dikatakan bahwa untuk mata pelajaran IPS kelas IV B , siswa yang dinyatakan lulus $65 \%$, dan yang masih harus mengikuti remidi adalah $35 \%$.

Proses pembelajaran yang bersifat teacher center terjadi di SD Negeri Tukangan, pada saat pembelajaran IPS. Guru berfungsi sebagai pusat pembelajaran dengan menggunakan metode ceramah dan belum menggunakan media berbasis IT. Metode klasikal yang diterapkan oleh guru di SD Negeri Tukangan kurang mampu motivasi siswa untuk menyukai pelajaran IPS akibatnya hasil belajar IPS siswa kelas IV kurang optimal. Permasalahan rendahnya motivasi siswa juga terjadi di SD Negeri Tukangan, khususnya kelas IV B.

Sebagian siswa kurang aktif dalam proses pembelajaran IPS. Mereka diam dan cenderung malu bila diberi kesempatan bertanya oleh guru. Kurangnya motivasi belajar siswa ini dipengaruhi oleh metode mengajar guru yang monoton, karena sebagian besar proses pembelajaran menggunakan metode ceramah tanpa ada variasi serta belum ada pemanfaatan IT sebagai media pembelajaran. Siswa malas untuk mengembangkan daya nalarnya mengenai permasalahan IPS yang disampaikan oleh guru pada saat pembahasan pelajaran.

Untuk menghadapi masalah rendahnya motivasi siswa serta belum optimalnya hasil belajar siswa kelas IV $\mathrm{B}$, guru sebagai tenaga pendidik harus mencari metode yang tepat dipergunakan dalam pembelajaran IPS. Guru diberi kebebasan untuk berkreasi dalam mendesain proses pembelajaran. Namun metode pembelajaran tidak boleh membatasi ruang kreatifitas siswa untuk mengkonstruksi ide-ide mereka. Untuk itu perlu dipilih metode yang mampu memotivasi siswa untuk ikut aktif dalam proses pembelajaran, dan akhirnya dapat mengoptimalkan hasil belajar.

Salah satu metode pembelajaran yang dapat digunakan untuk menyelesaikan permasalahan rendahnya motivasi serta belum optimalnya hasil belajar siswa di kelas IV B SD Negeri Tukangan adalah dengan menerapkan metode pembelajaran kooperatif yang memasukkan unsurunsur keterlibatan siswa secara langsung. Seperti yang dikemukakan oleh Anita Lie (2007) pembelajaran kooperatif mampu menghasilkan prestasi yang lebih tinggi, memotivasi seluruh siswa untuk memanfaatkan seluruh energi sosial siswa, dan melatih sikap tanggung jawab sehingga menuntut keaktifan aktif dari setiap anggota kelompok.

Salah satu model pembelajaran kooperatif yang digunakan dalam pembalajaran adalah Teams Game Tournament (TGT). Teams Game Tournament (TGT) merupakan bagian 
dari pembelajaran kooperatif yang menggabungkan kelompok belajar dengan kompetisi kelompok, dan bisa digunakan untuk meningkatkan pembelajaran beragam fakta, materi pokok atau keterampilan. Teams Game Tournament (TGT) menggunakan pertandingan atau kompetisi akademik, di mana para siswa memiliki kemampuan akademik yang sama dari setiap kelompok akan saling berkompetisi. Dalam Teams Game Tournament (TGT) keberhasilan lebih diorientasikan pada keberhasilan kelompok dari pada keberhasilan individu.

Pembelajaran kooperatif tipe TGT mudah diterapkan, melibatkan aktivitas seluruh siswa tanpa harus ada perbedaan status, melibatkan peran siswa sebagai tutor sebaya dan mengandung unsur permainan dan reinforcement. Aktivitas belajar dengan permainan yang dirancang dalam pembelajaran kooperatif tipe

TGT memungkinkan siswa dapat belajar lebih rileks disamping menumbuhkan tanggung jawab, kerjasama, persaingan sehat dan keterlibatan belajar.

Menurut Slavin (2005:163-167) tahapan-tahapan dalam Teams Game

Tournament (TGT) yang perlu diperhatikan adalah sebagai berikut :

\section{1) Presentasi Kelas (Class Presentations)} Dalam presentasi guru menyampaikan materi pembelajaran secara garis besar saja. Kegiatan ini bertujuan untuk mempersiapkan kondisi siswa dalam mengikuti pelajaran. Kemudian ada beberapa siswa yang mewakili setiap kelompok untuk mempresentasikan materi yang baru saja diberikan oleh guru.

2) Belajar Kelompok (Teams)

Kelompok terdiri dari empat sampai lima orang yang heterogen misalnya dalam hal kemampuan akademis, jenis kelamin, suku bangsa, dan etnis. Tujuan utama dari belajar kelompok adalah untuk meyakinkan bahwa semua siswa dalam kelompok benar-benar belajar, dan semua anggota mempersiapkan diri untuk mengikuti permainan dan kompetisi dengan sebaik-baiknya. Diharapkan tiap anggota kelompok melakukan hal terbaik bagi kelompoknya dan ada usaha kelompok untuk membantu anggota-anggota kelompoknya sehingga dapat meningkatkan kemampuan akademik dan menumbuhkan pentingnya kerja sama diantara siswa dan meningkatkan rasa percaya diri siswa.

3) Permainan (Games)

Permainan (games) dibuat dengan isi pertanyaan-pertanyaan untuk mengetahui sejauh mana pengetahuan dan pemahaman siswa setelah presentasi kelas dan belajar kelompok. Ketika pelaksanaan games siswa mengambil kartu bernomor dan berusaha menjawab pertanyaan sesuai dengan nomor. Aturan dalam games memperbolehkan setiap peserta games untuk merebut pertanyaan yang tidak bisa dijawab atau pun pertanyaan yang dapat dijawab namun belum benar dalam permainan.

4) Kompetisi (Tournament)

Kompetisi (tournament) biasanya diselenggarakan akhir minggu atau setiap materi bahasan selesai, setelah guru melakukan presentasi kelas dan kelompok- kelompok mempraktikkan tugas-tugasnya. Untuk kompetisi pertama guru menetapkan siapa yang akan bertanding di meja turnamen. Menetapkan tiga siswa peringkat atas dalam kriteria yang lalu di meja 1, masing-masing siswa mewakili timnya. Tiga siswa berikutnya pada meja 2, dan seterusnya. Kompetisi ini merupakan sistem penilaian kemampuan perorangan dalam TGT, memungkinkan bagi siswa untuk dari semua level di penampilan sebelumnya untuk memaksimalkan 
nilai kelompok mereka menjadi yang terbaik. Setelah seminggu pertama tersebut, siswa dapat berpindah tergantung pada kinerja mereka sendiri. Pemenang pada tiap meja naik ke meja yang lebih tinggi berikutnya, siswa yang memperoleh skor kedua tetap pada posisi meja yang sama, dan siswa yang mendapat skor yang paling rendah turun ke meja yang paling rendah.

5) Penghargaan Kelompok ( Teams Recognition)

Setelah mengikuti games dan tournament, setiap kelompok akan memperoleh point. Rata-rata point kelompok yang diperoleh dari games dan tournament akan digunakan sebagai penentu penghargaan kelompok. Apabila rata-rata point kelompok yang diperoleh melewati kriteria yang ditentukan maka kelompok tersebut berhak memperoleh penghargaan. Penghargaan kelompok dapat berupa hadiah, sertifikat, dan sebaginya. Team mendapat julukan "Super Team" jika rata-rata skor 50, "Great Team" apabila rata-rata mencapai 45 dan "Good Team" apabila rata-ratanya 40.

Metode cooperative learning tipe TGT diharapkan mampu merangsang motivasi belajar siswa. Motivasi memiliki pengaruh yang sangat besar terhadap kesuksesan sebuah pengajaran. Bila siswa sudah memiliki motivasi belajar yang baik, maka pembelajaran dan tingkah laku siswa selama pembelajaran juga akan baik dan kelas akan mewujudkan disiplin yang baik dan pembelajaran akan efektif. Sebaliknya, jika motivasi belajar siswa buruk maka semua usaha guru untuk mengkondisikan kelas akan sia-sia.

Istilah motivasi berasal dari bahasa Latin "movere" yang artinya bergerak. Menurut Hamzah B. Uno (2007:3) "istilah motivasi berasal dari kata motif yang dapat diartikan sebagai kekuatan yang terdapat dalam diri individu, yang menyebabkan diri individu itu bertindak atau berbuat". Nana Syaodih Sukmadinata (2005:61), bahwa "kekuatan yang menjadi pendorong kegiatan individu disebut motivasi, yang menunjukkan kondisi dalam diri individu yang mendorong atau menggerakkan individu tersebut melakukan kegiatan mencapai suatu tujuan". Disimpulkan bahwa pada dasarnya semua perbuatan atau kegiatan manusia dapat terwujud karena adanya dorongan atau latar belakang dalam melakukan perbuatan tersebut.

Pendapat dari Sardiman (2009:84) "motivation is an essential condition of learning". Hasil belajar akan menjadi optimal kalau ada motivasi siswa untuk belajar. Makin tepat motivasi yang diberikan, akan berhasil pula proses belajar dan hasil belajar. Jadi motivasi berkaitan erat dengan hasil belajar siswa. Menurut Sumadi Suryabrata (2006:296) "hasil belajar meliputi perubahan psikomotorik, sehingga hasil belajar adalah kemampuan siswa yang berupa penguasaan pengetahuan, sikap, dan keterampilan yang dicapai setelah ia melakukan kegiatan belajar".

Pengklasifikasian hasil belajar dalam pendidikan nasional, rumusan tujuan pendidikan baik tujuan kurikuler maupun tujuan instruksional menggunakan klasifiksi belajar dari Bloom. Menurut Blom (Suharsimi Arikunto. 2003:115) secara garis besar membagi tiga ranah, yang dikenal dengan "taksonomi Bloom yaitu ranah kognitif, ranah afektif, dan ranah psikomotorik." Ketiga ranah tersebut menjadi obyek hasil belajar, di mana masing-masing ranah terdiri dari sejumlah aspek yang saling berkaitan, dan alat penilaian untuk setiap ranah juga mempunyai karakteristik sendirisendiri, sebab setiap ranah berbeda 
dalam cakupan dan hakikat yang terkandung di dalamnya.

Untuk lebih mengoptimalkan motivasi dan hasil belajar siswa, selain dengan menggunakan metode pembelajaran kooperatif, juga memanfaatkan IT untuk membuat media pembelajaran yang menarik. Salah satunya dengan Lectora Inspire. Lectora merupakan software yang digunakan untuk memenuhi kebutuhan pembelajaran baik secara online maupun offline, serta pembuatannya cukup mudah. Lectora dapat digunakan untuk menggabungkan flash, merekam video, menggabungkan gambar, dan screen capture.

Lectora mampu memperbaiki kekurangan yang ada di program power point, karena dalam Lectora banyak sekali library yang memudahkan guru untuk menggunakan aplikasi gambar, template, screen capture tanpa perlu mengunduh dari internet. Di dalam Lectora juga memuat program untuk mencantumkan standar kompetensi dan kompetensi dasar yang harus dikuasai siswa. Dengan Lectora ini diharapkan mampu membantu para guru untuk membuat media pembelajaran yang menarik bagi siswa tapi tidak menyulitkan bagi guru.

\section{Metode Penelitian}

Penelitian ini merupakan penelitian tindakan kelas atau sering disebut dengan classroom action research. Penelitian ini mengambil bentuk kolaborasi. Kolaboratif artinya peneliti berkolaborasi atau bekerja sama dengan guru mata pelajaran IPS, tergabung dalam satu tim untuk melakukan penelitian dengan tujuan untuk memperbaiki kekurangankekurangan dalam praktek pembelajaran. Penelitian dilakukan di SD Negeri Tukangan pada kelas IV B semester 2 tahun ajaran 2012/2013. Penelitian dilaksanakan dalam 2 siklus.

Subyek dalam penelitian ini adalah siswa kelas IV B SD Negeri Tukangan. Penentuan subyek penelitian ini menggunakan teknik purposive sampling. Dalam penelitian ini yang dijadikan kriteria dan pertimbangan adalah motivasi belajar siswa, dan hasil belajar siswa pada mata pelajaran IPS. Oleh karena itu yang dijadikan subyek penelitian adalah kelas yang tingkat motivasi belajar dan hasil belajarnya kurang optimal bila dibandingkan kelas IV lainnya. Pengambilan kelas IV B sebagai subyek dalam penelitian ini juga berdasarkan hasil konsultasi dengan kepala sekolah dan guru yang mengajar di kelas IV, sehingga mempermudah peneliti dalam memperoleh informasi mengenai perkembangan kondisi siswa dalam mengikuti pembelajaran IPS.

Teknik pengumpulan data dalam penelitian ini menggunakan angket untuk mengetahui tingkat motivasi belajar siswa, wawancara untuk mengetahui tanggapan/pendapat guru IPS dan siswa kelas IV B mengenai pembelajaran sebelum menggunakan metode TGT berbantuan Lectora dan setelah menggunakan metode TGT berbantuan Lectora, tes hasil belajar digunakan untuk mendapatkan data mengenai peningkatan hasil belajar selama siswa menggunakan metode Teams Game Tournament (TGT) berbantuan Lectora. Tes terdiri dari pre test, post siklus I dan post tes siklus II, dokumentasi, dan catatan lapangan untuk mengetahui kelebihan dan kekurangan yang ada selama menggukan metode dan media ini. Teknik analisis datanya meliputi data reduction, data display, dan verification. Validitas yang digunakan meliputi validitas rasional/ logis dari expert judgement serta validitas empiris dengan pengolahan data uji coba instrumen.

\section{Hasil Penelitian}

Pelaksanaan pembelajaran kooperatif tipe teams games tournament pada 
setiap siklusnya dapat dideskripsikan sebagai berikut.

\section{Siklus I}

\section{a. Perencanaan Tindakan}

Pada tahap perencanaan, instrumen yang dipersiapkan oleh peneliti sebagai berikut:

1) Perencanaan tindakan dimulai dengan mempersiapkan materi yang akan diberikan dalam kegiatan pembelajaran dengan materi pokok "Perkembangan Teknologi".

2) Menyusun RPP yang akan digunakan sebagai acuan guru dalam pelaksanaan pembelajaran dengan tipe TGT.

3) Menyiapkan media berbantuan Lectora.

4) Menyiapkan media berupa kertas pertanyaan dan kertas jawaban untuk game dan tournament.

5) Menyiapkan lembar penilaian untuk game dan tournament.

6) Menyusun soal untuk pre tes dan post tes.

7) Menyiapkan LKS.

8) Menyiapkan lembar penilaian untuk mengetahui peningkatan hasil belajar siswa tiap siklus.

9) Menyiapkan pedoman wawancara untuk guru dan siswa.

10) Menyiapkan lembar catatan lapangan untuk mencatat semua kegiatan yang terjadi selama tindakan.

11) Menyiapkan peralatan untuk mendokumentasikan kegiatan selama proses pembelajaran berlangsung seperti kamera.

\section{b. Pelaksanaan Tindakan}

Pada tahap pelaksanaan tindakan, guru melaksanakan pembelajaran dengan metode pembelajaranl kooperatif tipe TGT berbantuan Lectora berdasarkan RPP yang sebelumnya telah disiapkan oleh peneliti. Sebelum digunakan RPP terlebih dahulu dikonsultasikan dengan guru kelas.

\section{1) Pertemuan $\mathbf{I}$}

Pada pertemuan pertama, kegiatan yang dilakukan adalah pre tes.

\section{2) Pertemuan II}

Penyampaian materi masih menggunakan metode ceramah dengan dibantu oleh media Lectora. Dalam tahap teaching, materi yang dipelajari mengenai perkembangan teknologi produksi dan komunikasi. Dalam menyampaikan materi guru terkadang memberikan pertanyaan untuk menarik perhatian dan konsentrasi siswa, tapi masih banyak siswa yang malu untuk menjawab. Guru kurang mampu memotivasi siswa untuk aktif menjawab pertanyaan.

Setelah tahap teaching selesai kemudian dilanjutkan tahap team study. Sebelum team study atau diskusi kelompok dilakukan, peneliti membagi siswa ke dalam kelompok-kelompok kecil. Pembagian kelompok dengan memperhatikan heterogenitas siswa berdasarkan jenis kelamin dan prestasi akademik. Siswa dibagi menjadi 6 kelompok, masing-masing kelompok terdiri dari 4-5 siswa. Guru menginstruksikan siswa menempatkan diri sesuai kelompoknya masingmasing. Namun tidak semua kelompok bergegas untuk membentuk kelompok. Ada siswa yang lupa dengan anggota kelompoknya sehingga banyak siswa yang maju ke depan dan berebut untuk menanyakan kelompoknya kepada guru sehingga suasana kelas menjadi gaduh.

Setelah semua siswa menempatkan diri dalam kelompoknya masing- masing, kemudian diadakan diskusi kelompok sesuai dengan LKS yang diberikan oleh peneliti. Setiap kelompok mendapatkan materi yang berbeda untuk dibahas.

Diskusi kelas berlangsung selama 15 menit. Pada team study atau diskusi siklus I, siswa terlihat antusias mengerjakan LKS, namun ada beberapa siswa yang tidak ikut berdiskusi, justru berbicara dengan teman dari kelompok lain, ada juga siswa yang cuma melamun saja. Guru 
tidak menegur siswa yang berbicara sendiri atau pun melamun.

Setelah diskusi selesai, kemudian dilanjutkan dengan presentasi masingmasing kelompok secara bergiliran. Semua anggota kelompok maju ke depan kelas untuk mempresentasikan hasil diskusinya. Dalam presentasi kelas siswa diberi kesempatan untuk bertanya. Namun masih banyak siswa yang malu untuk bertanya, kemudian guru memotivasi siswa untuk berani bertanya dan yang berani bertanya akan diberi reward tambahan nilai. Siswa menjadi bersemangat untuk bertanya, ada tiga orang siswa yang bertanya. Selesai siswa mengajukan pertanyaan, guru memberikan reinforcement dengan menyuruh siswa secara bersama-sama memberikan applause dan pujian untuk siswa yang berani bertanya.

\section{3) Pertemuan III}

Pelaksanaan tindakan pada pertemuan ketiga ini meliputi game and tournament dan post tes siklus I. Sebelum game and tournament dimulai, peneliti menjelaskan aturan game dan tournament.

Langkah-langkah dalam permainan TGT sebagai berikut:

a) Pada putaran game I salah satu siswa mewakili kelompok I (siswa A) maju ke meja tournament yaitu meja yang di atasnya diletakkan kartu pertanyaan dan kartu jawaban yang sudah diberi nomor. Siswa tersebut mengambil satu kartu pertanyaan yang sudah diberi nomor.

b) Siswa tersebut membacakan keraskeras yang ada dalam kartu yang dia ambil.

c) Kemudian anggota kelompok I lainnya menjawab pertanyaan yang dibacakan. Jawaban siswa harus sesuai dengan yang tertera pada kartu jawaban. Siswa diberi waktu 2 menit untuk menjawab, apabila dalam 2 menit jawaban siswa tidak sesuai atau tidak bisa menjawab maka pertanyaan dilemparkan pada kelompok lain. Bila siswa menjawab benar skor yang diperoleh 1, bila menjawab kurang tepat atau salah skor yang diperoleh 0 .

d) Selanjutnya perwakilan kelompok II (siswa A) maju ke meja tournament untuk mengambil lembar pertanyaan kemudian membacakan keras-keras pertanyaan yang tertera dalam kartu pertanyaan dan anggota kelompok II lainnya harus menjawab pertanyaan sesuai kartu jawaban, apabila dalam 2 menit jawaban kutang tepat atau tidak bisa menjawab maka pertanyaan akan dilemparkan pada kelompok lainnya. Begitu seterusnya bergantian sampai kelompok VI.

e) Pada putaran ke II, dimulai dengan perwakilan siswa kelompok I (siswa B), dilanjutkan kelompok II (siswa B), dan seterusnya sampai putaran ke III dan kartu pertanyaan habis terjawab.

Pada siklus pertama masih banyak perwakilan kelompok yang lama dalam menjawab pertanyaan sehingga pertanyaan banyak dilempar ke kelompok lain. Situasi saat game dan tournament gaduh karena bila ada perwakilan kelompok yang maju maka semua kelompok bersemangat mengacungkan jari untuk menjawak kelompok yang meskipun bukan giliran kelompoknya yang menjawab. Guru dan peneliti agak kesulitan mengkondusifkan siswa. Setelah game and tournament selesai, kemudian dilanjutkan dengan post tes siklus I. Post tes siklus I terlaksana dengan cukup sukses. Hampir semua siswa berkonsentrasi mengerjakan soal dengan tenang

\section{c . Hasil Tindakan}

Berdasarkan hasil tindakan pada siklus I diperoleh hasil sebagai berikut:

\section{Motivasi Belajar Siswa}

Berdasarkan hasil olah data angket motivasi belajar siswa, diperoleh data sebagai berikut:

1) Hasil Angket Motivasi Belajar Siswa Pada Saat Pre Tes 
Dari hasil olah data angket motivasi belajar siswa yang diberikan saat pre tes kepada 27 siswa, diperoleh sebanyak 8 siswa memiliki motivasi tinggi, 14 siswa memiliki motivasi belajar sedang, dan 5 siswa memiliki motivasi belajar rendah. Bila diukur dengan persentase maka $29,63 \%$ siswa memiliki motivasi tinggi, 51,85 \% siswa memiliki motivasi sedang, dan 18,52\% siswa memiliki motivasi rendah.

2) Hasil Angket Motivasi Belajar

Siswa Pada Siklus I

Dari hasil olah data angket motivasi belajar siswa yang diberikan setelah siklus I berakhir kepada 27 siswa, diperoleh sebanyak 18 siswa memiliki motivasi tinggi, 9 siswa memiliki motivasi belajar sedang, dan 0 siswa memiliki motivasi belajar rendah. Bila diukur dengan persentase maka $66,67 \%$ siswa memiliki motivasi tinggi, $33,33 \%$ siswa memiliki motivasi sedang, dan $0 \%$ siswa memiliki motivasi rendah.

\section{Hasil Belajar Siswa}

Berdasarkan hasil olah data tes hasil belajar siswa, diperoleh data sebagai berikut:

1) Hasil Belajar Siswa Pada Saat Pre Tes

Dari hasil olah data untuk instrumen uji kemampuan belajar siswa yang diberikan saat pre tes kepada 27 siswa, diperoleh sebanyak 19 siswa tuntas dalam belajar, dan 8 siswa tidak tuntas. Batas ketuntasan diukur dari nilai yang diperoleh minimal 65 . Bila diukur dengan persentase maka $70,37 \%$ siswa tuntas dalam belajar, dan 29,63\% siswa tidak tuntas dalam belajar.
2)Hasil Tes Hasil Belajar Siswa Pada Siklus I

Dari hasil olah data tes hasil belajar siswa yang diberikan setelah siklus I berakhir kepada 27 siswa, diperoleh sebanyak 23 siswa tuntas dalam belajar, dan 4 siswa tidak tuntas dalam belajar. Bila diukur dengan persentase maka $85,19 \%$ siswa tuntas dlam belajar, $14,81 \%$ siswa tidak tuntas dalam belajar

\section{d. Refleksi dan Evaluasi}

Refleksi pada siklus I dilakukan dengan mengkaji hasil tindakan serta permasalahan yang dihadapi selama tindakan pada siklus I berlangsung. Pada siklus I diperoleh data bahwa siswa kurang antusias dalam tahap teaching namun sudah antusias dalam tahap game and tournamnet. Dalam tahap teaching, banyak siswa kurang antusias karena guru menjelaskannya masih monoton meskipun menggunakan media Lectora tapi guru lebih banyak ceramah.

Ada beberapa kelemahan yang ditemukan dalam siklus I, antara lain:

1. Penjelasan guru belum menarik perhatian siswa karena cendurung ceramah.

2. Tampilan media Lectora kurang menarik, sehingga siswa kurang antusias.

3. Posisi tempat duduk antar kelompok yang terlalu dekat sehingga memungkinkan siswa untuk saling mengganggu anggota kelompok lain.

4. Belum ada kesadaran dari dalam diri siswa untuk berani bertanya dan mengemukakan pendapat, peran guru masih besar untuk memotivasi siswa agar mau bertanya, meskipun cara guru dalam memotivasi siswa belum maksimal.

5. Siswa banyak yang protes bila hendak menjawab pertanyaan tidak diijinkan oleh guru karena 
bukan giliran kelompoknya yang menjawab, sehingga menimbulkan kegaduhan saat game.

6. Peneliti kesulitan dalam mengelola kertas pertanyaan dan kertas jawaban pada saat game berlangsung.

Berdasarkan hasil analisis dan refleksi siklus I, langkah selanjutnya pada siklus II kelemahan harus bisa diminimalisis dan rancangan tindakan harus dapat menarik perhatian siswa dan memotivasi siswa untuk belajar dan berprestasi dalam game.

\section{e. Tindak Lanjut}

Untuk meningkatkan motivasi belajar IPS dan hasil belajar IPS pada siswa kelas IV B, peneliti melakukan diskusi dengan guru kelas untuk merancang pengurangan kelemahan pada siklus I. Dari hasil diskusi tersebut diperoleh pemecahan kelemahan sebagai berikut:

1. Pada saat teaching guru lebih banyak melakukan tanya jawab untuk mengeksplorasi pengetahuan siswa dibandingkan dengan ceramah. Untuk menghindari kebosanan siswa ditengah-tengah materi ada ice breaking dengan chicken dance.

2. Memperbaiki tampilan media Lectora.

3. Mengatur posisi kelompok agar tidak terlalu berdekatan untuk memilimalisir gangguan antar kelompok dan agar mobilitas peneliti saat observasi menjadi lebih leluasa.

4. Memacu siswa agar lebih berani mengajukan pertanyaan dan mengemukakan pendapat, dengan memberikan poin tambahan bagi siswa yang berani bertanya atau memberikan pendapat.

5. Agar siswa tidak protes saat ingin menjawab pertanyaan dalam tahap game, maka ada peraturan bila belum ada aba-aba dari guru yang mengijinkan siswa kelompok lain untuk menjawab maka tidak boleh ada yang mengacungkan tangan. Setelah ada aba-aba dari guru baru kelompok lain yang bukan giliran maju boleh berebut menjawab.

6. Peneliti membagi kertas pertanyaan yang sudah diurutkan di sebelah kanan dan kertas jawaban yang sudah diurutkan berada di sebelah kiri, kemudian di tengah disediakan kotak yang digunakan untuk meletakkan kertas pertanyaan dan kertas jawaban yang sudah diseselaikan siswa.

\section{Siklus II}

a. Perencanaan Tindakan

Pada dasarnya secara teknis pelaksanaan pembelajaran pada siklus ke II sama dengan siklus I namun dengan memperhatikan hasil refleksi yang diperoleh pada siklus I.

\section{b. Pelaksanaan Tindakan}

\section{1). Pertemuan I}

Pada pertemuan pertama meliputi tahap teaching dan team study. Dalam tahap teaching, materi yang dipelajari mengenai perkembangan teknologi transportasi. Penyampaian materi masih menggunakan metode ceramah namun sudah lebih banyak disertai tanya jawab. Untuk menghindari kebosanan, siswa di tengah-tengah penjelasan materi, guru dan siswa melakukan ice breaking berupa chicken dance. Dengan ice breaking tersebut siswa bisa meregangkan otot-otot dan pikiran.

Setelah tahap teaching selesai kemudian dilanjutkan tahap team. Sebelum presentasi kelas, guru menginstruksikan siswa menempatkan diri sesuai kelompoknya masing-masing. Semua kelompok langsung menempatkan pada posisi tempat duduk yang telah ditentukan. Peneliti membantu mengatur posisi duduk kelompok.

Setelah semua siswa menempatkan diri dalam kelompoknya masing- masing, kemudian diadakan diskusi kelompok 
mengenai materi yang tadi diberikan oleh guru. Setiap kelompok mendapatkan materi yang berbeda untuk

dibahas. Diskusi kelompok pada siklus II berjalan dengan tertib dan lancar. Setelah diskusi selesai dilanjutkan dengan presentasi kelompok. Pada siklus II sudah ada beberapa siswa yang berani mengajukan pertanyaan tanpa disuruh oleh guru, bahkan banyak yang menambahkan jawaban. Siswa yang berani bertanya akan diberi reward tambahan nilai. Siswa juga tidak malu melontarkan pendapatnya atau menyanggah pendapat temannya. Selesai siswa mengajukan pertanyaan dan pendapat, guru juga memberikan reinforcement dengan menyuruh siswa secara bersama-sama memberikan applause dan pujian untuk siswa yang berani bertanya.

\section{2) Pertemuan II}

Pelaksanaan tindakan pada pertemuan kedua ini meliputi game and tournament, team recognition, dan post tes II. Pada tahap game and tournament, guru menginstruksikan siswa untuk menempatkan diri dalam kelompoknya masing-masing. Setelah seluruh siswa siap dalam kelompoknya, peneliti membagikan media untuk game dan tournament.

Setelah semua kartu jawaban dan kartu pertanyaan diurutkan sesuai nomor, permainan TGT dimulai. Semua siswa terlihat senang mengikuti game. Setiap anggota kelompok termotivasi untuk memperoleh skor tertinggi. Bila ada anggota kelompok yang maju ke depan, maka anggota kelompok yang lain berdiri dan memberikan semangat pada temannya yang maju ke depan. Setiap anggota kelompok solid, bila ada giliran kelompoknya menjawab pertanyaan tetapi perwakilan kelompoknya tersebut tidak bisa menjawab maka anggota kelompok lainnya sigap untuk mencari jawaban yang benar. Semua kelompok bersemangat karena pada siklus II ini adalah kesempatan untuk menambah skor kelompok.

Situasi saat game dan tournament sudah lebih tenang dibandingkan siklus I karena anggota kelompok takut didiskualifikasi. Posisi tempat duduk setiap kelompok lebih teratur sehingga mobilitas peneliti menjadi lebih leluasa. Guru juga lebih mudah mengkondusifkan suasana kelas.

Setelah semua kartu pertanyaan habis terjawab maka diumumkan hasil perolehan skor yang diperoleh masingmasing kelompok berdasarkan keaktifan ketika presentasi dan game siklus I dan II maka yang memperoleh skor tertinggi dengan predikat juara I adalah kelompok VI, disusul berikutnya juara II oleh kelompok III dan juara III diperoleh kelompok II.

Guru membesarkan hati kelompok I, IV, dan $\mathrm{V}$ agar jangan patah semangat karena masih ada kesempatan untuk memperbaiki skor kelompoknya bila dilaksanakan game dengan model lainnya. Mendengar penjelasan dari guru semua siswa menjadi termotivasi untuk lebih berprestasi. Setelah skor diumumkan, masing-masing kelompok yang menjadi juaran maju ke depan untuk mendapatkan hadiah dari peneliti. Masing-masing kelompok terlihat sangat gembira dan bangga. Setelah tahap team recognition, kemudian dilanjutkan dengan post tes siklus II. Post tes siklus II berjalan dengan cepat dan lancar.

\section{c. Hasil Tindakan}

Berdasarkan hasil tindakan pada siklus II diperoleh hasil tindakan sebagai berikut:

\section{Motivasi Belajar Siswa}

Dari hasil olah data angket motivasi belajar siswa yang diberikan setelah siklus II berakhir kepada 27 siswa, diperoleh sebanyak 22 siswa memiliki motivasi tinggi dan 5 siswa memiliki motivasi belajar sedang, dan 0 siswa memiliki motivasi belajar rendah. Bila diukur dengan persentase maka $81,48 \%$ 
siswa memiliki motivasi tinggi, $18,52 \%$ siswa memiliki motivasi sedang, dan $0 \%$ siswa memiliki motivasi rendah. Berikut diagram batang yang menunjukkan peningkatan motivasi belajar siswa dari pre tes, siklus I dan siklus II:

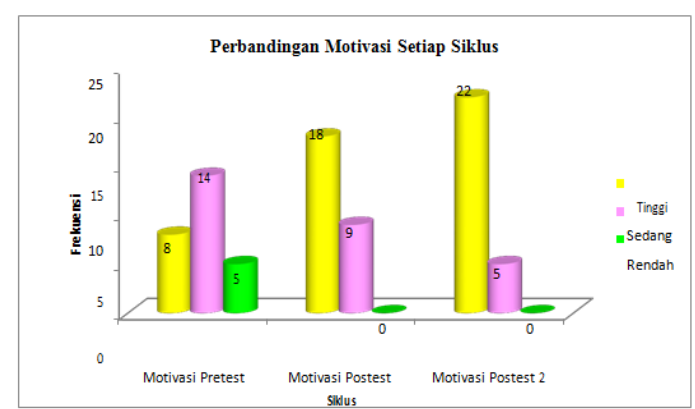

Diagram 1. Motivasi Belajar Pre Tes, Siklus I dan II

\section{Hasil Belajar Siswa}

Dari hasil olah data tes hasil belajar siswa yang diberikan setelah siklus II berakhir kepada 27 siswa, diperoleh sebanyak 27 siswa tuntas dalam belajar. Bila diukur dengan persentase maka 100 $\%$ siswa tuntas dalam belajar.

Jika dibandingkan dengan hasil belajar saat pre tes dan siklus I maka hasil belajar siswa pada kuis siklus II dapat dikatakan mengalami peningkatan. Peningkatan ini dapat dilihat dari persentase ketuntasan. Kenaikan ini dikarenakan, siswa sudah lebih memperhatikan dan aktif dalam mengikuti proses pembelajaran. Berikut disajikan diagram batang hasil belajar siswa saat pre tes, kuis siklus I, kuis siklus II dilihat dari ketuntasan:

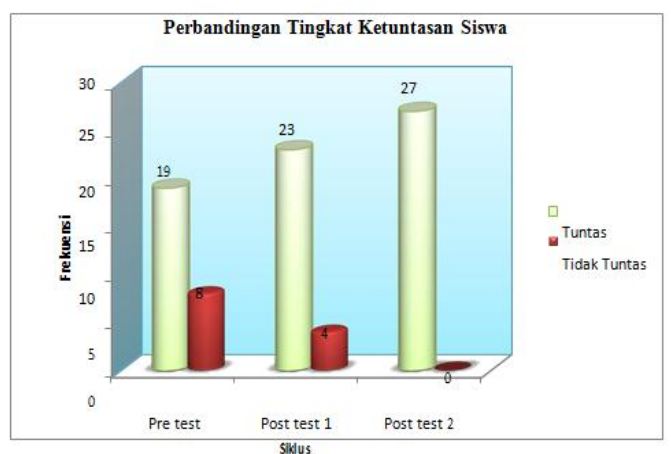

Diagram 2. Hasil belajar pre tes, kuis siklus I \&II
Selain dilihat dari ketuntasan belajar, kenaikan hasil belajar siswa juga terlihat dari kenaikan nilai rata-rata. Nilai rata-rata hasil belajar untuk pre tes sebesar 68,79, nilai rata-rata hasil belajar untuk siklus I sebesar 79,54, dan nilai rata-rata hasil belajar untuk siklus II sebesar 87,77. Berikut disajikan diagram batang hasil belajar siswa saat pre tes, kuis siklus I, kuis siklus II dilihat dari rata-rata nilai:

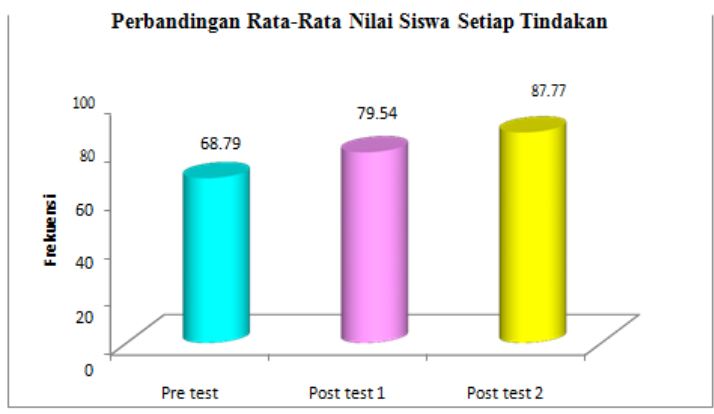

Diagram 3. Rata-rata Hasil Belajar Pre Tes, Siklus I dan II

\section{d. Refleksi dan Evaluasi}

Refleksi pada siklus II dilakukan dengan mengkaji hasil tindakan, observasi dan wawancara serta permasalahan yang dihadapi selama tindakan pada siklus II berlangsung. Hasil penelitian ini secara keseluruhan menunjukan adanya peningkatan motivasi belajar dan hasil belajar siswa dalam proses pembelajaran dengan menggunakan TGT berbantuan Lectora. Siswa sudah dapat mengikuti pembelajaran dengan metode TGT secara optimal. Hal ini dapat dilihat dari antusiasme siswa dalam setiap tahapan yang ada dalam TGT, mulai dari teaching, team study, presentasi kelas, game \& tournament, terlebih lagi ketikan tahap team recognize.

\section{Pembahasan}

Metode pembelajaran kooperatif tipe TGT merupakan tipe pembelajaran kooperatif yang menggabungkan antara belajar kelompok dengan kompetisi kelompok. Dari permasalahan 
pembelajaran IPS yang terjadi di kelas IV B SD Negeri Tukangan, peneliti tertarik untuk menerapkan metode pembelajaran kooperatif model TGT dalam upaya meningkatkan motivasi, dan hasil belajar siswa. Seperti yang dikemukakan oleh Anita Lie (2007) pembelajaran kooperatif mampu menghasilkan prestasi yang lebih tinggi, memotivasi seluruh siswa untuk memanfaatkan seluruh energi sosial siswa, dan melatih sikap tanggung jawab.

Dalam pembelajaran kooperatif tipe TGT, selain ditanamkan kemampuan untuk bekerja sama kepada siswa, dalam pembelajaran juga dilaksanakan kompetisi dalam bentuk game dan tournament. Dua struktur tujuan, yaitu kooperatif dan kompetitif digabungkan dalam pembelajaran tipe TGT. Dengan adanya struktur tujuan kooperatif, siswa akan menikmati aktifitas belajarnya, baik menang maupun kalah. Dengan adanya struktur kompetitif, siswa akan termotivasi untuk menjadi yang terbaik dengan cara meningkatkan prestasi belajarnya. Dengan demikian motivasi dan hasil belajar akan meningkat.

Upaya peningkatan motivasi dan hasil belajar IPS siswa dengan pembelajaran kooperatif tipe TGT dilakukan dengan mengacu pada tahapan dalam TGT yang menurut Slavin (2005) meliputi teaching, belajar kelompok, game dan tournament, penghargaan kelompok. Setelah tindakan berupa penerapan model pembelajaran kooperatif tipe TGT dilakukan melalui beberapa tahap, terjadi peningkatan motivasi dan hasil belajar IPS siswa. Peningkatan motivasi belajar siswa selama pelaksanaan tindakan antara lain dapat dilihat dari peningkatan persentase dari lembar angket motivasi belajar siswa. Sedangkan untuk hasil belajar dapat dilihat dari nilai evaluasi.

Tahap pertama dalam pembelajaran kooperatif tipe TGT adalah teaching. Teaching dilakukan oleh guru dengan menyampaikan materi yang dipelajari kepada siswa. Dalam melakukan tahap teaching, guru sering mengaitkan konsep yang sedang dipelajari dengan contohcontoh yang relevan dengan kehidupan sehari-hari siswa. Setelah tahap teaching, kemudian dilanjutkan dengan tahap team study, yaitu siswa berdiskusi dalam kelompoknya. Pada tahap belajar kelompok siswa mempelajari materi secara berkelompok. Pembelajaran dalam kelompok lebih diarahkan untuk menyelesaikan tugas atau LKS bersama. Masing- masing kelompok terdiri dari 4-5 siswa, setiap kelompok mendiskusikan sub pokok bahasan yang berbeda. Setelah berdiskusi, masingmasing kelompok mempresentasikan hasil diskusinya dilanjutkan dengan tanya jawab.

Tahap selanjutnya adalah game and tournament. Pada tahap ini perwakilan dari masing-masing kelompok maju ke depan kelas dan mengambil satu kertas pertanyaan kemudian membaca keraskeras isi pertanyaan. Pertanyaan harus dijawab oleh anggota kelompoknya. Jawaban harus sesuai dengan kertas jawaban yang sudah dicocokkan nomornya.

$\begin{array}{lllr}\quad \text { Dalam } & \text { game } & \text { and tournament, } \\ \text { digunakan } & \text { media } & \text { berupa kertas } \\ \text { pertanyaan } & \text { dan } & \text { kertas jawaban }\end{array}$ menggunakan warna dan gambar yang menarik. Media ini dipilih dengan menitikberatkan pada aktifitas dan keterlibatan siswa dalam pembelajaran. Media yang menarik dan bervariasi merupakan salah satu alat bantu dalam proses pembelajaran. Bila media yang digunakan dalam setiap proses pembelajaran selalu sama maka lama kelamaan siswa akan cepat jenuh. Karena itu diperlukan media yang selalu bervariasi di setiap proses pembelajaran sehingga siswa tidak cepat jenuh. Sehubungan dengan hal ini Syaiful Bahri

Djamarah dan Aswan Zain (2006:122) berpendapat bahwa "proses belajar mengajar dengan bantuan media diyakini dapat mempertinggi kegiatan belajar anak didik dalam waktu yang 
cukup lama. Itu berarti kegiatan anak didik dengan bantuan media akan menghasilkan proses dan hasil belajar yang lebih baik dari pada tanpa bantuan media."

Tahap terakhir adalah penghargaan kelompok (team recognition). Penghargaan kelompok diberikan berdasarkan poin yang dikumpulkan oleh setiap kelompok dalam kegiatan pembelajaran. Bagi kelompok yang berhasil mengumpulkan poin terbanyak maka kelompok tersebut berhak untuk memperoleh penghargaan. Penghargaan kelompok merupakan salah satu cara untuk meningkatkan motivasi dan hasil belajar siswa. Dengan adanya penghargaan kelompok siswa akan termotivasi untuk belajar sehingga hasil belajar pun akan meningkat. Hal ini senada dengan pernyataan yang diutarakan oleh siswa saat wawancara bahwa siswa pantang menyerah berlomba-lomba untuk bisa memperoleh reward dengan point tertinggi.

Dalam penelitian ini pembelajaran kooperatif tipe TGT dilaksanakan dalam dua siklus. Setiap siklus dilakukan pengumpulan data menggunakan angket mengenai motivasi belajar dan tes untuk mengukur hasil belajar siswa. Pada saat pre tes, motivasi belajar siswa yang berada dalam kategori tinggi sebesar $29,63 \%$, yang berada dalam kategori sedang sebesar $51,85 \%$, yang berada dalam kategori rendah sebesar 18,51\%. Pada siklus I terjadi kenaikan, siswa yang memiliki motivasi tinggi sebesar $66,67 \%$, yang memiliki motivasi sedang sebesar 33,33\%. Pada siklus II, motivasinya naik kembali, siswa yang memiliki motivasi tinggi sebesar $81,48 \%$ dan sisanya $18,52 \%$ memiliki motivasi sedang.

Berdasarkan hasil wawancara dengan guru, motivasi belajar siswa mengalami peningkatan karena siswa jadi lebih termotivasi belajar karena mereka ingin berprestasi dan bagi siswa yang berprestasi akan diberikan reward. Sejalan dengan hal ini dengan pendapat
Sardiman (2009) bahwa "cara untuk menumbuhkan motivasi dalam kegiatan belajar di sekolah salah satunya dengan pemberian hadiah serta dengan menumbuhkan kesadaran kepada siswa agar merasakan pentingnya tugas dan menerimanya sebagai tantangan sehingga bekerja keras dengan mempertaruhkan harga diri."

Variabel selanjutnya yang diamati dalam penelitian ini adalah hasil belajar siswa. Hasil belajar digunakan sebagai suatu gambaran dari penguasaan kemampuan para peserta didik sebagaimana telah ditetapkan untuk suatu pelajaran tertentu. Berdasarkan hasil tes, diperoleh data perbandingan antara nilai saat pre tes, siklus I dan siklus II dapat dikatakan rata-rata nilai mengalami peningkatan. Peningkatan ini selain dapat dilihat dari ketuntasan, juga dapat dilihat melalui peningkatan rata-rata. Hasil belajar siswa dilihat dari ketuntasannya, untuk pre tes

$70,37 \%$ tuntas dan $29,63 \%$ tidak tuntas, untuk post tes siklus I $85,18 \%$ tuntas dan

$14,81 \%$ tidak tuntas, untuk post tes siklus II $100 \%$ tuntas. Dilihat dari ratarata nilainya terjadi kenaikan, untuk pre tes rata-rata nilainya 68,79 , post tes siklus I rata-rata nilainya 79,54, dan post tes siklus II rata-rata nilainya 87,77 . Kenaikan ini dikarenakan, siswa mereka termotivasi untuk belajar agar dapat memperoleh nilai yang baik.

Dalam hubungannya dengan keefektifan belajar kelompok, pengaturan tempat duduk merupakan salah satu hal yang memegang peranan cukup penting. Posisi tempat duduk dalam belajar kelompok sebaiknya diatur sedemikian rupa agar siswa dapat secara leluasa bekerja bersama anggota kelompoknya sehingga semua siswa dapat berpartisipasi aktif selama belajar kelompok berlangsung. Selama pembelajaran dalam siklus I, posisi tempat duduk antar kelompok yang terlalu dekat sehingga memungkinkan 
siswa untuk saling mengganggu anggota kelompok lain. Selain itu posisi tempat duduk menyulitkan mobilitas peneliti untuk melakukan observasi mengenai perhatian dan motivasi belajar siswa. Untuk meningkatkan keefektifan dalam belajar kelompok, selanjutnya posisi tempat duduk diubah untuk siklus II.

Posisi tempat duduk siswa dibuat urut dari bangku paling depan sebelah kanan untuk kelompok I, seterusnya kelompok II dan kelompok VI di bangku paling belakang untuk meminimalisir gangguan antar kelompok serta memudahkan guru dan peneliti melakukan observasi. Sehubungan dengan pengaturan posisi tempat duduk dalam pembelajaran kooperatif, Anita Lie (2007:52) mengemukakan bahwa :

Dalam pembelajaran kooperatif penataan ruang kelas perlu memperhatikan prinsip-prinsip tertentu. Bangku perlu ditata sedemikian rupa sehingga semua siswa dapat melihat guru/papan tulis dengan jelas, bisa melihat rekan-rekan kelompoknya dengan baik, dan berada dalam jangkauan kelompoknya dengan merata. Kelompok bisa dekat satu sama lain tapi tidak mengganggu kelompok yang lain dan guru bisa menyediakan sedikit ruang kosong di salah satu bagian kelas untuk kegiatan lain.

Setelah dilakukan perbandingan data yang diperoleh dari hasil lembar observasi, wawancara, dan dokumentasi, peneliti menyimpulkan bahwa melalui tahapan dalam TGT berbantuan Lectora yang terdiri atas teaching, team, game and tournament, team recognition dapat meningkatkan motivasi belajar siswa dan hasil belajar IPS siswa kela IV B SD Negeri Tukangan.

\section{Simpulan dan Saran}

Berdasarkan pembahasan yang telah dilakukan pada bab sebelumnya dapat disimpulkan bahwa dengan penerapan metode pembelajaran kooperatif tipe Teams Games Tournament (TGT) berbantuan Lectora dapat meningkatkan motivasi belajar dan hasil belajar IPS siswa kelas IV B SD Negeri Tukangan.

Saran saran peneliti berdasarkan kesimpulan dalam penelitian ini adalah hendaknya guru selalu melakukan variasi metode pembelajaran dilengkapi sarana dan prasarana yang mendukung pemanfaatkan IT dalam proses pembelajaran dapat meningkatkan motivasi belajar dan hasil belajar siswa. Untuk pihak sekolah hendaknya mampu meminimalisis keterbatasan sarana prasana pembelajaran terkait dengan fasilitas penunjang IT.

\section{Daftar Rujukan}

Anita Lie. (2007). Cooperative Learning Mempraktikkan Cooperative Learning di Ruang-ruang Kelas. Jakarta: Gramedia.

Hamzah B. Uno. (2007). Teori Motivasi dan Pengukurannya Analisis di Bidang Pendidikan. Jakarta: Bumi Aksara.

Nana Syaodih Sukmadinata. (2005). Landasan psikologi proses pendidikan. Bandung: Rosdakarya.

Sardiman, A.M. (2009). Interaksi dan Motivasi Belajar Mengajar. Jakarta: PT Raja Grafindo Persada.

Suharsimi Arikunto. (2003). Dasardasar Evaluasi Pendidikan. Jakarta:Bumi Aksara.

Slavin. (2005). Cooperative Learning Teori, Riset dan Praktik. Nusa Media: Bandung.

Syaiful Bahri Djamarah\& Aswan Zein. (2006). Strategi Belajar Mengajar. Jakarta: Rineka Cipta. 